\title{
COMPARATION STUDY OF SOIL GENETIC DIVERSITY OF BACTERIA AND FUNGI IN DIFFERENT VEGETATION SUCCESSIONS IN A KARST OF GUIZHOU PROVINCE, CHINA
}

\author{
PRIMERJALNA ŠTUDIJA GENETSKE RAZNOVRSTNOSTI TALNIH \\ BAKTERIJ IN GLIV V RAZLIČNIH SUKCESIJAH VEGETACIJE NA \\ KRASU V PROVINCI GUIZHOU, KITAJSKA
}

\author{
Yidong $\mathrm{MI}^{1,2}$, Hongda $\mathrm{FANG}^{3}$, Peng $\mathrm{TAO}^{4}$, Min $\mathrm{ZHOU}^{1,5}$, Xinru $\mathrm{LI}^{1}$, Fanfan WANG ${ }^{1}$,

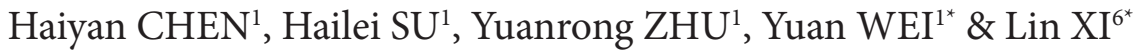

\begin{abstract}
UDC 582.231:551.435.8(513)

582.28:551.435.8(513)

Yidong Mi, Hongda Fang, Peng Tao, Min Zhou, Xinru Li, Fanfan Wang, Haiyan Chen, Hailei Su, Yuanrong Zhu, Yuan Wei \& Lin Xi: Comparation study of soil genetic diversity of bacteria and fungi in different vegetation successions in a karst of Guizhou province, China

To study the soil genetic diversity of bacteria and fungi in different vegetation successions (grassland, shrubbery, primary forest and secondary forest) from the karst area, the Polymerase Chain Reaction-Denaturing Gradient Gel Electrophoresis (PCR-DGGE) technology was applied. The results showed that: (1) the diversity of bacterial communities and the fungal communities in karst area were higher than non karst area in each vegetation succession. Compared with the survey from bacterial (the Shannon index was 2.97 in primary forest, 2.91 in secondary forest, 3.18 in shrubbery, 3.14 in grassland and 2.68 in non karst), fungal diversity between karst areas (the Shannon index was 3.56 in primary forest, 3.78 in secondary forest, 3.73 in shrubbery and 3.70 in grassland) and non karst areas (the Shannon index was 3.08) was more evident, which may be related to the alterations of the composition of plant community and the source of carbon in soil with the vegetation succession of karst ecosystem; (2) The comparation of bacterial diversity index and the richness comprehensively
\end{abstract}

Izvleček

UDK 582.231:551.435.8(513)

Yidong Mi, Hongda Fang, Peng Tao, Min Zhou, Xinru Li, Fanfan Wang, Haiyan Chen, Hailei Su, Yuanrong Zhu, Yuan Wei \& Lin Xi: Primerjalna študija genetske raznovrstnosti talnih bakterij in gliv $v$ različnih sukcesijah vegetacije na krasu $v$ provinci Guizhou, Kitajska

$\mathrm{Za}$ proučevanje genetske pestrosti talnih bakterij in gliv $\mathrm{v}$ različnih sukcesijah vegetacije (travišče, grmičevje, primarni gozd in sekundarni gozd) na krasu je bila uporabljena tehnologija verižne reakcije s polimerazo-denaturirajoča gradientna gelska elektroforeza (PCR-DGGE). Rezultati raziskave so pokazali, da: (1) je bila v vsaki sukcesiji vegetacije pestrost bakterijskih in glivnih združb na kraškem območju višja kot na nekraškem. V primerjavi z bakterijsko raznovrstnostjo (Shannonov indeks je bil 2,97 v primarnem gozdu, 2,91 v sekundarnem gozdu, 3,18 v tleh grmičevja, 3,14 v tleh travišč in $2,68 \mathrm{v}$ nekraškem območju) je bila raznovrstnost gliv med kraškimi območji (Shannonov indeks je bil v primarnem gozdu 3,56, $3,78 \mathrm{v}$ sekundarnem gozdu, $3,73 \mathrm{v}$ tleh grmičevja in $3,70 \mathrm{v}$ tleh travišč) in nekraškimi (Shannonov indeks je bil 3,08) jasneje izražena. To je lahko povezano s spremembami v sestavi rastlinske združbe in vira ogljika $v$ tleh glede na stanje sukcesije v vegetaciji kraškega ekosistema. (2) Primerjava kazalnikov bakterijske raznovrstnosti in abundance je bila celostno ovred-

\footnotetext{
${ }^{1}$ State Key Laboratory of Environmental Criteria and Risk Assessment, Chinese Research Academy of Environmental Science, Beijing 100012, P.R. China, e-mails: m18363974562@163.com,15712975290@163.com,18813145607@163.com, wwffaannaza@126.com,chenhy@craes.org.cn,suhailei666@163.com,zhuyuanrong07@mails.ucas.ac.cn,rbq-wy@163.com

${ }^{2}$ School of Resources Environment and Chemical Engineering, Nanchang University, Nanchang 330031, P.R. China, e-mail: m18363974562@163.com

${ }^{3}$ School of Port and Environmental Engineering, Jimei University, Xiamen 361021, P.R. China, e-mail: hdfang@jmu.edu.cn

${ }^{4}$ State Key Laboratory of Environmental Geochemistry, Institute of Geochemistry, Chinese Academy of Sciences, Guiyang 550081, P.R. China, e-mail: pengtao@mails.gyig.ac.cn

${ }^{5}$ College of Environment, Hohai university, Nanjing 210098, P.R. China, 15712905290@163.com

${ }^{6}$ Department of Plant Systems Biology, University of Hohenheim, 70599 Stuttgart, Germany, e-mail: lin.xi.260@uni-hohenheim.de

* Corresponding Author
} 
evaluated as follows: shrubbery $>$ grassland $>$ primary forest $>$ secondary forest. The diversity index and the richness of fungal communities was as follows: secondary forest $>$ shrubbery $>$ grassland $>$ primary forest. The results suggest that the fungal communities have been greatly changed via vegetation successions, but the diversity index and the richness of the bacterial communities have not been seriously affected. The results provide scientific basis for understanding karst surface ecosystem, which contributes to the future aim of protecting the karst from desertification.

Keywords: karst; vegetation succession; bacteria; fungi; genetic diversity. notena in sledi takole: grmičevje $>$ travišče $>$ primarni gozd $>$ sekundarni gozd. Kazalnika raznovrstnosti in abundance glivnih združb kažeta sledeči trend: sekundarni gozd > grmičevje $>$ travišče > primarni gozd. Rezultati izkazujejo, da so se glivne združbe precej spremenile zaradi sukcesije v vegetaciji, vendar pa na drugi strani ni bilo bistvenega vpliva na kazalnika bakterijske raznovrstnosti in abundance. Rezultati med drugim dajejo tudi znanstveno podlago za razumevanje delovanja kraškega površinskega ekosistema, kar ključno prispeva k cilju zaščite krasa pred dezertifikacijo (širjenjem puščav).

Ključne besede: kras, sukcesija vegetacije, bakterije, glive, genetska pestrost.

\section{INTRODUCTION}

Karst area in Southwest China is one of the most typical tropical-subtropical karst regions in the world (Yan et al., 2020). Karst topography is a result of geological action of soil erosion, which is dominated by chemical dissolution and supplemented by the mechanical actions of erosion or collapse (Zhou et al., 2020). This reflects in soil alkalinity, surface drought and nutrient deficiency (Wang et al., 2004; Zhang et al., 2015). One of the most harmful consequences of ecosystem degradation in karst regions is rocky desertification-development of a desert-like landscape with large-scale exposure of bedrock due to severe human disturbances (Liu et al., 2018). Southwest China is known as the ecological barrier of the Yangtze River because of its abundant ecological diversity, complex natural environment and ecological structure $(\mathrm{Wu}$ et al., 2018). Rocky desertification has tremendously threated the ecological security of this region, restricted sustainable economic development and consequently affected the whole Yangtze river ecological balance. Therefore, to study the ecological restoration of rocky desertification is necessary for sustainable development and human survival (Hui et al., 2019).

Although the rocky desertification process is partly due to its natural foundations (lithology, climate, etc.) and is influenced by different human social conditions (population, economy, etc.) (Ma et al., 2020), soil microorganisms play a key role in this process (Wei et al., 2011; Jiang et al., 2014). Microorganisms are widely distributed in soil, and play an important role in the transformation and circulation of organic matter, nitrogen, phosphorus, sulfur and other plant nutrients (Blagodatskaya \& Kuzyakov, 2013; Chen et al., 2019). Soil microorganisms are crucial promoters of soil evolution, property change, soil fertility and biomass production, it has a profound influence on the disstribution and succession process of vegetation in different stages in karst areas. Soil microorganisms are sensitive to environmental change, which can indicate the change of ecosystem (Kumar et al., 2015). Therefore, the study of microbial diversity in karst areas is conducive to in-depth karst formation factors and provides supporting materials for karst ecological restoration. Meanwhile, microorganisms mainly feed on plant and animal secretion and organic matter, and the composition of plant species community in turn can significantly affect the community structure of soil microorganisms (Carney \& Matson, 2005; Fan et al., 2019). Zhao et al. (2014) have studied the soil microorganisms along a progressive succession of secondary vegetation in a karst area and found that microbial biomass and ratio of fungal to bacterial biomass decreased with the secondary succession in the plant community. Li et al. (2013) found that vegetation changes from trees to shrubs and shrubs to grass might affect soil organic carbon contents particularly for organic carbon fractions, and alter soil microbial biomass, community structures and enzyme activities. Previous studies have provided that in karst area, different vegetation types give rise to the distinction on microbial community structure in soil in the aspect of the biomass (He et al., 2008; Zhu et al., 2012; Pan et al., 2018). However, there is a lack of discussion on genetic diversity of soil microorganisms. Thus characterization of soil microorganisms from different vegetation succession types is needed.

In this study, the soil bacterial and fungal genetic diversity of different vegetation successions in karst region was studied using PCR and denaturing gradient gel electrophoresis (DGGE). The variation of soil microbial community structure in different vegetation succession stages was discussed. These results could definite the influence of ecological succession on soil microbial community structure and provided important scientific basis for the mechanism of rocky desertification of karst ecosystem, protection and management. 


\section{GEOLOGICAL AND GEOGRAPHICAL SETTING}

Maolan national nature reserve is located in Libo, Guizhou province, with an average altitude of $758.8 \mathrm{~m}$. This region has a typical subtropical monsoon humid climate, and the karst landform is very developed in this area (Wei et al., 2012). The mean annual air temperature at Maolan is about $17^{\circ} \mathrm{C}$. Long-term mean annual precipitation of this region is around $1752 \mathrm{~mm}$, about $81 \%$ of which falls in the monsoon season from April to September (Liu et al., 2015a). There are vegetation succession communities with different degrees of degradation in this area, and the vegetation communities are relatively complete under each degree of degradation, which are conducive to the comparative study of different vegetation types in the same area.

The study was conducted at Laqiao Watershed, Yaogu Village, Yongkang Township $\left(25^{\circ} 18^{\prime} 00^{\prime \prime}-25^{\circ} 18^{\prime} 50^{\prime \prime} \mathrm{N}\right.$, $107^{\circ} 56^{\prime} 10^{\prime \prime}-107^{\circ} 58^{\prime} 10^{\prime \prime}$ ) ), Maolan National Natural Preserve, Guizhou province in southwest China (Figure 1) in August. According to the main characteristic of karst vegetation succession, four representative types of vegetation succession (grassland, shrubbery, primary forest and secondary forest) were selected. Grassland was dominated by herbaceous plants, the height of herbaceous layer was between $0.5-1 \mathrm{~m}$, and the coverage rate was above $90 \%$, the dominant species were Heteropogon contortus, Pteridium revolutum, Dicranopteris linearis, Miscanthus floridulus, etc. Shrubbery was mainly shrub layers with a height of 2.5-3 $\mathrm{m}$ and a coverage rate of more than $80 \%$, with a few trees, the vertical structure of the stand was simple, the dominant species were Nandina domestica, Lindera communis, Damnacanthus indicus, Clausena dunniana, Cyclobalanopsis multinervis, Rosa cymosa, etc. Primary forest was dominated by the arbor layer, which was $10-20 \mathrm{~m}$ high, the arbor layer covered more than $80 \%$, and the hierarchical structure was relatively complete, the dominant species were Pittosporum brevicalyx, Machilus microcarpa, Pteroceltis tatarinowii, Pittosporum glabratum, Euonymus dielsianus, Castanopsis fargesii, Mahonia fortunei, Ficus

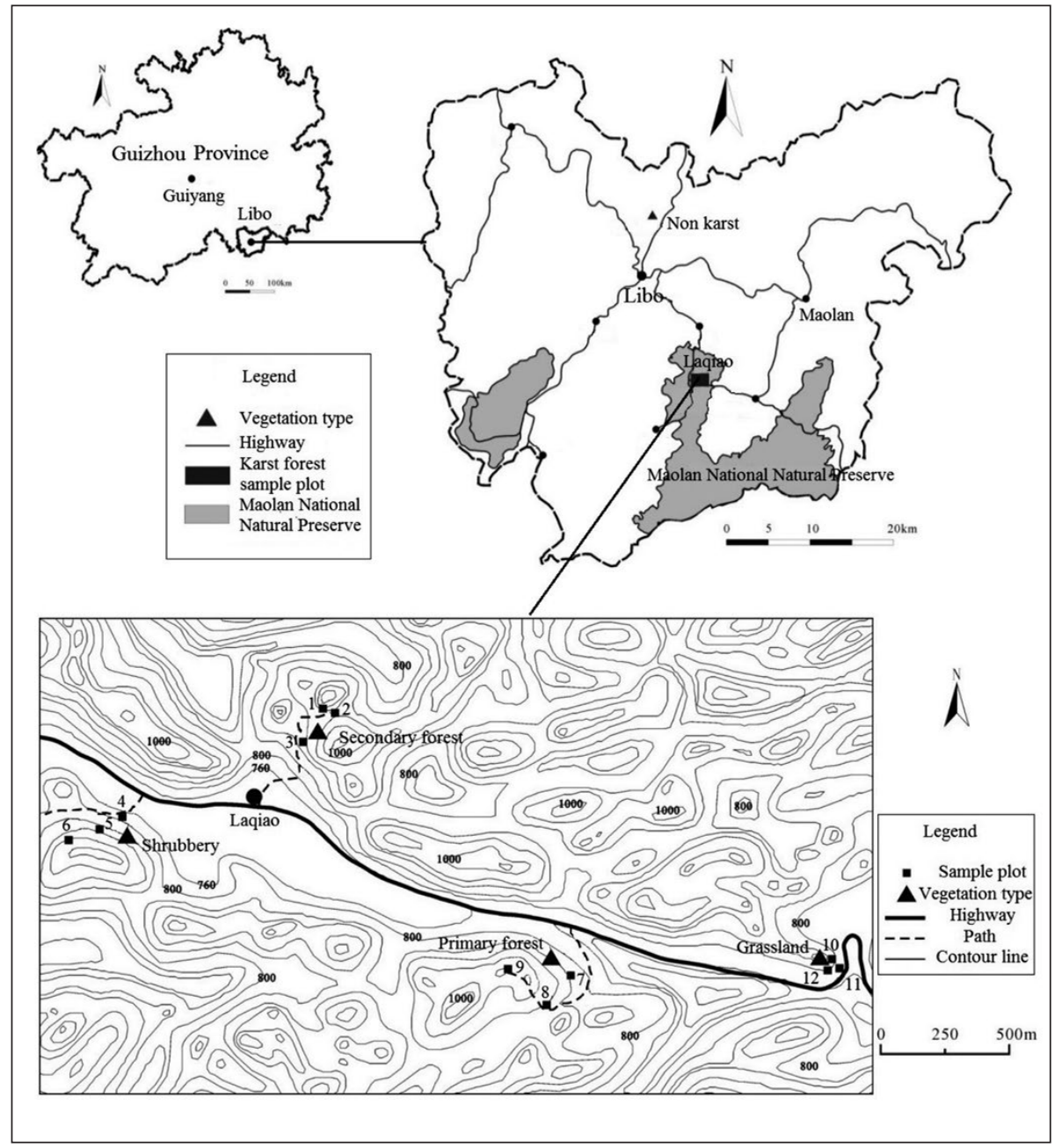

Figure 1: Descriptive map of the study area and the samples plots. 
YIDONG MI, HONGDA FANG, PENG TAO, MIN ZHOU, XINRU LI, FANFAN WANG, HAIYAN CHEN, HAILEI SU, YUANRONG ZHU, YUAN WEI \& LIN XI

Table 1: The vegetation characteristic of different vegetation succession.

\begin{tabular}{|l|c|c|c|l|}
\hline $\begin{array}{l}\text { Vegetation } \\
\text { succession }\end{array}$ & $\begin{array}{c}\text { Slope } \\
\text { inclination }\end{array}$ & $\begin{array}{c}\text { Rock } \\
\text { exposure rate }\end{array}$ & $\begin{array}{c}\text { Vegetation } \\
\text { coverage }\end{array}$ & $\begin{array}{l}\text { Vegetation } \\
\text { characteristic }\end{array}$ \\
\hline Primary forest & $30-40^{\circ}$ & $60-90 \%$ & $90-100 \%$ & $\begin{array}{l}\text { The hierarchical structure is complete, and the } \\
\text { differentiation between layers is distinct, mainly arbor layer, } \\
\text { the dominant species are arbor. }\end{array}$ \\
\hline $\begin{array}{l}\text { Secondary } \\
\text { forest }\end{array}$ & $30-40^{\circ}$ & $50-80 \%$ & $90-100 \%$ & $\begin{array}{l}\text { The hierarchical structure is obviously, and the arbor layer } \\
\text { and shrub layer are relatively developed. }\end{array}$ \\
\hline Shrubbery & $20-30^{\circ}$ & $70-80 \%$ & $80-100 \%$ & $\begin{array}{l}\text { The hierarchical structure is simple, the dominant species } \\
\text { are shrub. }\end{array}$ \\
\hline Grassland & $30-40^{\circ}$ & $50-70 \%$ & $90-100 \%$ & The dominant species are herbage. \\
\hline Non karst & $30-40^{\circ}$ & 0 & $90-100 \%$ & The dominant species are arbor. \\
\hline
\end{tabular}

erecta, etc. Secondary forest has developed arbor layer and shrub layer, with obvious differentiation of stand hierarchy structure, 5-12 m high, and tree layer coverage rate of more than $80 \%$, the dominant species were Carpinus pubescens, Cyclobalanopsis glauca, Castanopsis fargesii, Pinus massoniana, Pittosporum crispulum, Lindera communis, etc. Vegetation characteristics of different vegetation successions are shown in Table 1. Slope inclination measured with a forest compass, rock exposure rate and vegetation coverage were estimated by naked eye. Three typical sample plots of each vegetation succession were selected according to the principle of random distributed with local control (including density, slope direction and slope position), and the size of each sample plot was $20-30 \mathrm{~m}$.
In addition, three sample plots in a non karst vegetation succession of size $20-30 \mathrm{~m}$ in Libo country $\left(107^{\circ} 53^{\prime} 26^{\prime \prime} \mathrm{E}\right.$, $25^{\circ} 28^{\prime} 46^{\prime \prime} \mathrm{N}$ ) was chosen.

The sample plots were divided into the types of defined microhabitats (soil surface, stone ditch, stone seam and stone surface), the litters covering layer was removed, the weighted sampling method was adopted to collect the topsoil at 3-5 points $(0-15 \mathrm{~cm})$, and then the soil was screened at $2 \mathrm{~mm}$ to ensure sufficient mixing, and the samples were preserved at $-20^{\circ} \mathrm{C}$ (Wang et al., 2007). The soil here is rich in $\mathrm{Ca}^{2+}, \mathrm{Mg}^{2+}$, and $\mathrm{HCO}_{3}^{-}$, with a $\mathrm{pH}$ of 7.5 to 8.0 , an organic matter content of 75.5 to $380 \mathrm{~g} / \mathrm{kg}$, and a total nitrogen content of $6.06 \mathrm{~g} / \mathrm{kg}$ (Zhou, 1987; Wang et al., 2007).

\section{METHODS}

\section{DNA EXTRACTION AND PCR AMPLIFICATION OF $16 \mathrm{~S}$ rDNA GENES}

Total DNA was extracted from $0.5 \mathrm{~g}$ sample using Power Soil $^{\mathrm{TM}}$ DNA isolation kit (MO BIO laboratories, USA). DNA was finally preserved at $-80^{\circ} \mathrm{C}$ for later use.

The extracted DNA was used as templates for PCR. The amplification of bacterial DNA was performed using the universal 16S rDNA primers F338-GC (5'-CGCCCGCCGCGCGCGGCGGGCGGGGCGGGGGCACGGGGGGCCTACGGAGGCAGCAG-3') and R518 (5'-ATTACCGCGGCTGCTGG-3'). PCR was performed in a total volume of $25 \mu \mathrm{L}$, containing $1 \mu \mathrm{L}$ template solution, $12.5 \mu \mathrm{L}$ Master mix (Promega, M712B), $10 \mathrm{pmol}$ of each primer $(1 \mu \mathrm{L}), 9.5 \mu \mathrm{L} \mathrm{ddH}_{2} \mathrm{O}$. The PCR cycling parameters were $5 \mathrm{~min}$ at $94^{\circ} \mathrm{C}$ (the annealing temperature of each cycle decreased by $0.5^{\circ} \mathrm{C}$ ), and the last 100 cycles of $1 \mathrm{~min}$ at $94^{\circ} \mathrm{C}, 1 \mathrm{~min}$ at $65-55^{\circ} \mathrm{C}$, and $3 \mathrm{~min}$ at $72^{\circ} \mathrm{C}$, with a final extension phase of $7 \mathrm{~min}$ at $72^{\circ} \mathrm{C}$ (Muyzer et al., 1993).

The amplification of fungal DNA was performed using the universal $18 \mathrm{~S}$ rDNA primers U1
(5'-GACTCCTTGGTCCGTGTT-3') and U2-GC (5'-CGCCCGCCGCGCGCGGCGGGCGGGGCGGGGGCACGGGGGG-3'). PCR was performed in a total volume of $25 \mu \mathrm{L}$, containing $1 \mu \mathrm{L}$ template solution, $12.5 \mu \mathrm{L}$ Master mix (Promega, M712B), $1 \mu \mathrm{L}$ of each primer, $9.5 \mu \mathrm{L} \mathrm{ddH_{2 }} \mathrm{O}$. The PCR cycling parameters were $3 \mathrm{~min}$ at $94^{\circ} \mathrm{C}$, followed by 35 cycles of $0.5 \mathrm{~min}$ at $94^{\circ} \mathrm{C}$, $0.5 \mathrm{~min}$ at $53^{\circ} \mathrm{C}$, and $1 \mathrm{~min}$ at $72^{\circ} \mathrm{C}$, with a final extension phase of $10 \mathrm{~min}$ at $72^{\circ} \mathrm{C}$.

\section{DENATURING GRADIENT GEL ELECTROPHORESIS (DGGE) ANALYSIS}

The type 475 gradient irrigation system (Bio-Rad) was used to conduct the DGGE analysis. The PCR product of bacterial sample was analyzed on $8 \%$ polyacrylamide gels containing gradients of $30 \%$ to $60 \%$ denaturants. Electrophoresis was run at a constant voltage of $75 \mathrm{~V}$ for 10 $\mathrm{h}$ at $60^{\circ} \mathrm{C}$ in $1 \times \mathrm{TAE}$ running buffer. The gels were then stained with silver nitrate and scanned with an laser image analyzer (Bassam et al., 1991). 
The PCR product of fungal sample was analyzed on $8 \%$ polyacrylamide gels containing gradients of $30 \%$ to $70 \%$ denaturants. Electrophoresis was run at a constant voltage of $100 \mathrm{~V}$ for $10 \mathrm{~h}$ at $60^{\circ} \mathrm{C}$ in $1 \times \mathrm{TAE}$ running buffer. The gels were then stained with silver nitrate and scanned with a laser image analyzer.

\section{DATA ANALYSIS}

DGGE profiles from different samples were analyzed using Bio-Rad Quantity One 4.4.0 software (BIO-RAD, Hercules, CA, USA). Comparisons of banding profiles were performed by calculating the DICE correlation coefficient $(C s)$ using the unweighted pair group method with arithmetic mean (UPGMA) algorithm (Equation 1).

$C s=2 j /(a+b)$ $j$, indicates bands in common; $a$, indicates bands in sample $\mathrm{A} ; b$, indicates band in sample $\mathrm{B}$.

Richness $(S)$ is the total bands number of each sample. Shannon's index $(H)$ and evenness $(E h)$ were used to characterize microbial diversity, using the equations $2 \& 3$ :

$H=\sum_{i=1}^{S} P i \ln (P i)$

$E_{H}=H / H_{\max }=H / \ln S$

$H$, Shannon's index; $S$, total bands number of each sample; $P i$, relative abundance of $i$ th band of each sample (Luo et al., 2004). Data statistics was performed using Excel and SPSS v.17.1 software (SPSS Inc., Chicago, IL,USA).

\section{RESULTS}

\section{GENETIC DIVERSITY OF SOIL BACTERIA UNDER DIFFERENT VEGETATION SUCCESSIONS}

\section{DGGE spectrum analysis}

Bacterial communities associated with different soil samples were analysed by the DGGE profile (Figure 2).
DGGE analysis revealed that each sample contained several number of bands, each band represents different DNA sequence (Wei et al., 2012). It was obvious that some of the bands (bands no. 20, 24, 30 and 34) were detected across all samples, which suggested certain bacterial taxa were present in different karst areas and non

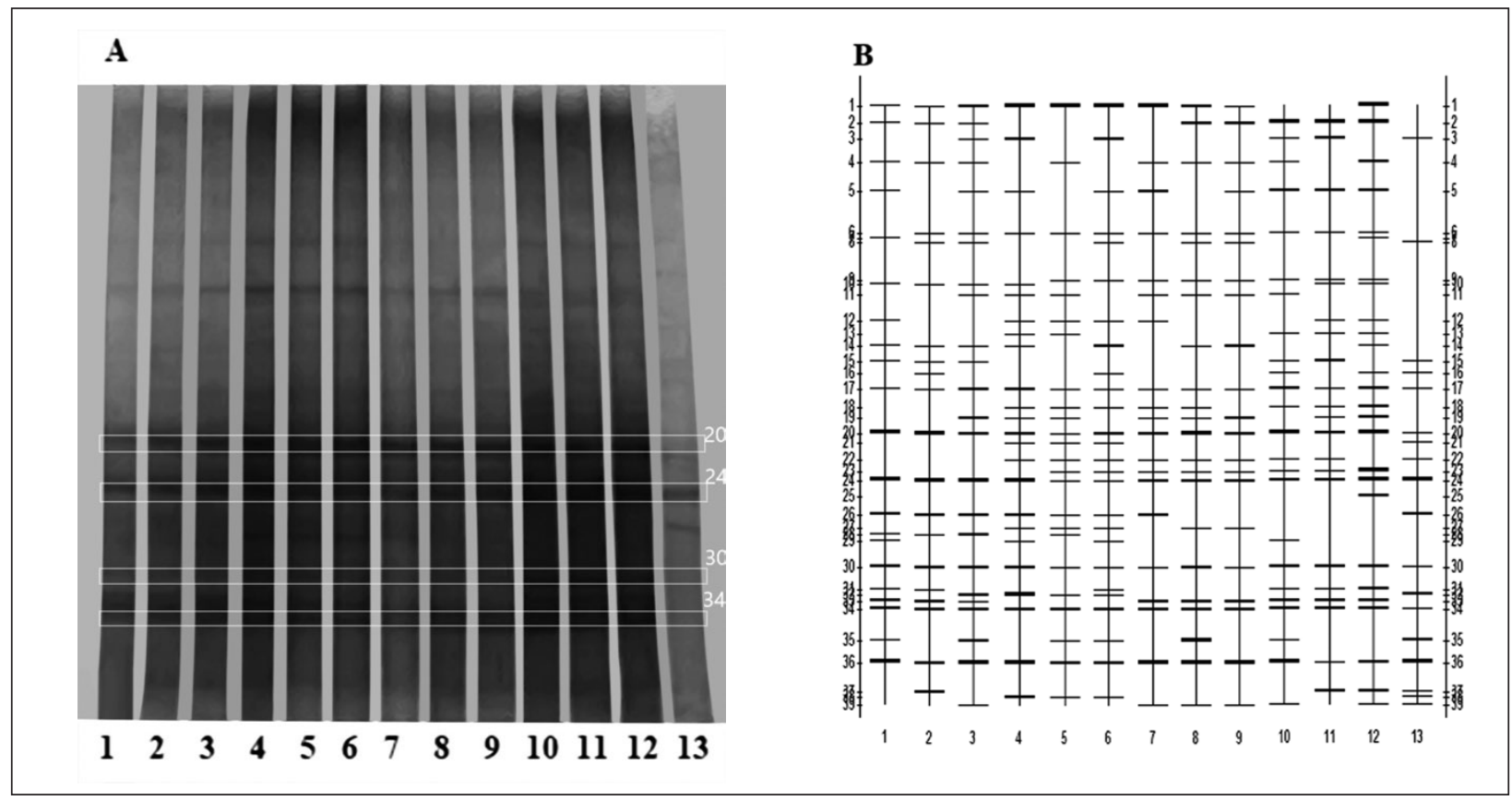

Figure 2: DGGE profile of amplified bacterial communities in different vegetation succession samples. (A) DGGE page; (B) Comparison of bands pattern (Horizontal numbers: 1-3 secondary forest; 4-6 shrub; 7-9 primary forest; 10-12 grassland; 13 non karst; Vertical numbers: 20, 24, 30 and 34 mark the positions of different bands.). 
karst area. Despite this, it showed much more specific electrophoretic bands in karst samples (sample 1-12) compared with non karst sample (sample 13). It indicated that soil bacterial species were more abundant and diverse in karst vegetation successions. From the DGGE profile, the shrub (sample 4,5 and 6) and the grassland (sample 10,11 and 12) exhibited the most abundant bands, an average of 25 bands out of 39 compared with others. Except the sample 13 (18 bands out of 39) from the non karst had the lowest quantity of bands, the secondary forest sample 1 and the primary forest sample 7 had relatively less bands, which were 21 bands out of 39 and 20 bands out of 39 , respectively. It could be possible that soil bacterial communities from the shrub and the grassland exhibited the highest diversity compared with other karst samples. At the same time, there are some common bands among the samples. For example band no. $20,24,30$ and 34 were commonly shared. In spite of that, the strong bands were commonly shared across the lanes suggested that the differences of dominant soil bacterial community among these karst vegetation successions were indistinctive (Yu et al., 2012). In general, the bacterial diversity in karst areas was obviously much higher than that in non karst area. There were some distinction in soil bacterial communities among karst vegetation successions, but the dominant population was relatively stable.

\section{Cluster analysis}

Based on the similarity of bacterial communities in different vegetation succession samples, cluster analysis was shown by a dendrogram (Figure 3 ), along with the similarity index between samples (Table 2). The dendrogram gave rise to two main branches of clusters and shared a similarity of 0.47 . One branch of cluster contains the sec- ondary forest and non karst, with the similarity of 0.57 . The other cluster covered the primary forest, shrub and the grassland. The bacterial communities between primary forest and shrub stayed closer with a similarity of 0.60 . The bacterial community of the grassland shared

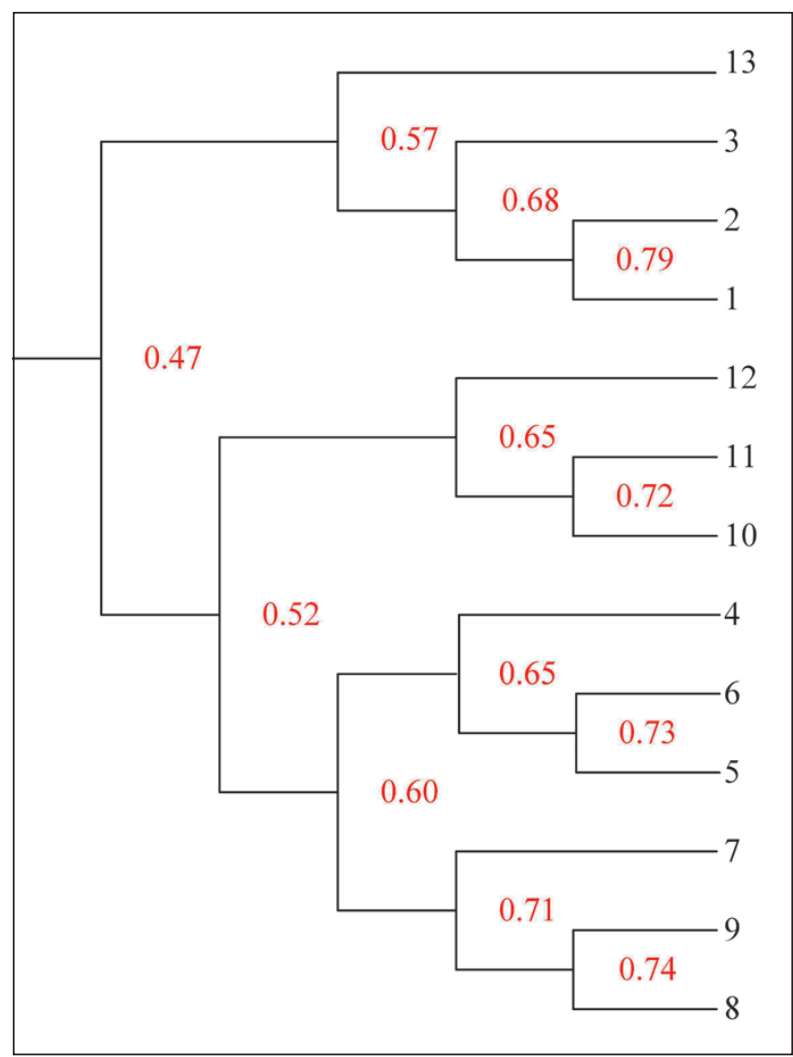

Figure 3: Cluster analysis of microbial communities between different vegetation succession samples. Numbers above the branches represent the Cs index. (1-3 secondary forest; 4-6 shrub; 7-9 primary forest; 10-12 grassland; 13 non karst).

Table 2: The similarity index (Cs) between different vegetation succession samples lanes of microbial communities (\%). (1-3 secondary forest; 4-6 shrub; 7-9 primary forest; 10-12 grassland; 13 non karst).

\begin{tabular}{|c|c|c|c|c|c|c|c|c|c|c|c|c|c|}
\hline Sample & 1 & 2 & 3 & 4 & 5 & 6 & 7 & 8 & 9 & 10 & 11 & 12 & 13 \\
\hline 1 & 100.0 & 78.0 & 68.5 & 49.5 & 40.0 & 44.0 & 60.5 & 61.2 & 57.5 & 62.9 & 46.2 & 46.0 & 59.5 \\
\hline 2 & 78.0 & 100.0 & 68.3 & 46.8 & 41.9 & 45.0 & 56.6 & 56.0 & 55.9 & 53.9 & 54.6 & 55.8 & 52.4 \\
\hline 3 & 68.5 & 68.3 & 100.0 & 64.5 & 52.0 & 54.6 & 61.0 & 63.1 & 59.9 & 57.7 & 48.7 & 51.0 & 57.8 \\
\hline 4 & 49.5 & 46.8 & 64.5 & 100.0 & 61.1 & 69.8 & 65.4 & 55.4 & 49.5 & 53.1 & 49.5 & 51.5 & 52.7 \\
\hline 5 & 40.9 & 41.9 & 52.0 & 61.1 & 100.0 & 72.9 & 67.8 & 57.3 & 51.9 & 42.8 & 40.8 & 44.7 & 47.7 \\
\hline 6 & 44.0 & 45.0 & 54.6 & 69.8 & 72.9 & 100.0 & 66.4 & 54.9 & 56.7 & 49.4 & 44.6 & 47.5 & 47.6 \\
\hline 7 & 60.5 & 56.6 & 61.0 & 65.4 & 67.8 & 66.4 & 100.0 & 69.8 & 71.4 & 58.9 & 53.7 & 55.3 & 47.2 \\
\hline 8 & 61.2 & 56.0 & 63.1 & 55.4 & 57.3 & 54.9 & 69.8 & 100.0 & 74.2 & 69.0 & 54.4 & 58.5 & 43.5 \\
\hline 9 & 57.5 & 55.9 & 59.9 & 49.5 & 51.9 & 56.7 & 71.4 & 74.2 & 100.0 & 59.5 & 52.2 & 52.1 & 39.0 \\
\hline 10 & 62.9 & 53.9 & 57.7 & 53.1 & 42.8 & 49.4 & 58.9 & 69.0 & 59.5 & 100.0 & 71.6 & 66.2 & 40.3 \\
\hline 11 & 46.2 & 54.6 & 48.7 & 49.5 & 40.8 & 44.6 & 53.7 & 54.4 & 52.2 & 71.6 & 100.0 & 64.5 & 30.1 \\
\hline 12 & 46.0 & 55.8 & 51.0 & 51.5 & 44.7 & 47.5 & 55.3 & 58.5 & 52.1 & 66.2 & 64.5 & 100.0 & 26.3 \\
\hline 13 & 59.5 & 52.4 & 57.8 & 52.7 & 47.7 & 47.6 & 47.2 & 43.5 & 39.0 & 40.3 & 30.1 & 26.3 & 100.0 \\
\hline
\end{tabular}


the similarly with the others of 0.52 . From the similarity index, non karst 13 had high correlation with secondary forest 1 (59.5\%), $2(52.6 \%)$ and $3(57.8 \%)$ and the lowest correlation with grassland samples $11(30.1 \%)$ and 12 (26.3\%). Therefore it is possible that bacterial community distinguish significantly at different vegetation successions.

\section{Diversity and Richness analysis}

We calculated the diversity index of soil bacterial communities in different vegetation succession samples, using Shannon index, richness and evenness (Table 3). According to Table 3, the Shannon index and richness of shrub were the highest among all karst areas, which were 3.18 and 25, respectively. The second highest index values were from the grassland, which were 3.14 and 24 respectively. The primary forest and secondary forest were 2.97 and 21, 2.91 and 22, respectively, and significantly lower than that of other karst areas. The Shannon index and richness of non karst plot were only 2.68 and 18 , which were the lowest, and the mean difference in bacte- rial Shannon index between karst areas (3.05) and non karst area (2.68) was 0.37 (Figure 4). In terms of evenness index, non karst plot exhibited the lowest value, only 0.93 while the shrub and the grassland gave the highest value of 0.99 , secondary forest had a value of 0.95 and primary forest had a value of 0.98 . Thus it suggested that when the vegetation succession getting changed from grassland to secondary forest, the diversity of soil bacterial communities increased firstly and then decreased. Shrub seemed to own the highest bacterial diversity.

\section{GENETIC DIVERSITY OF SOIL FUNGAL UNDER DIFFERENT VEGETATION SUCCESSIONS}

\section{DGGE spectrum analysis}

Similar as bacterial study, fungal communities in different vegetation succession samples were compared by DGGE (Figure 5). There were both the conserved and specific bands from samples 1 to 12 , which indicated that there were both common and specific fungal populations in the soil at different vegetation successions

Table 3: Shannon index, richness and evenness of bacterial communities in different vegetation succession stage samples.

\begin{tabular}{|c|c|c|c|}
\hline Vegetation succession & Shannon index $(\mathrm{H})$ & Richness (S) & Evenness $\left(E_{H}\right)$ \\
\hline Primary forest & $2.97 \pm 0.04^{\mathrm{a}}$ & 21 & $0.98 \pm 0.00$ \\
\hline Secondary forest & $2.91 \pm 0.16^{b}$ & 22 & $0.95 \pm 0.03$ \\
\hline Shrub & $3.18 \pm 0.04^{c}$ & 25 & $0.99 \pm 0.00$ \\
\hline Grassland & $3.14 \pm 0.08^{c}$ & 24 & $0.99 \pm 0.00$ \\
\hline Non karst & $2.68 \pm 0.00^{d}$ & 18 & $0.93 \pm 0.00$ \\
\hline
\end{tabular}

Note: Data are the means \pm SD (Different letters “a, b, c," in the same column indicate significant differences at $\mathrm{P}<0.05$ with Tukey test for multiple comparisons.).

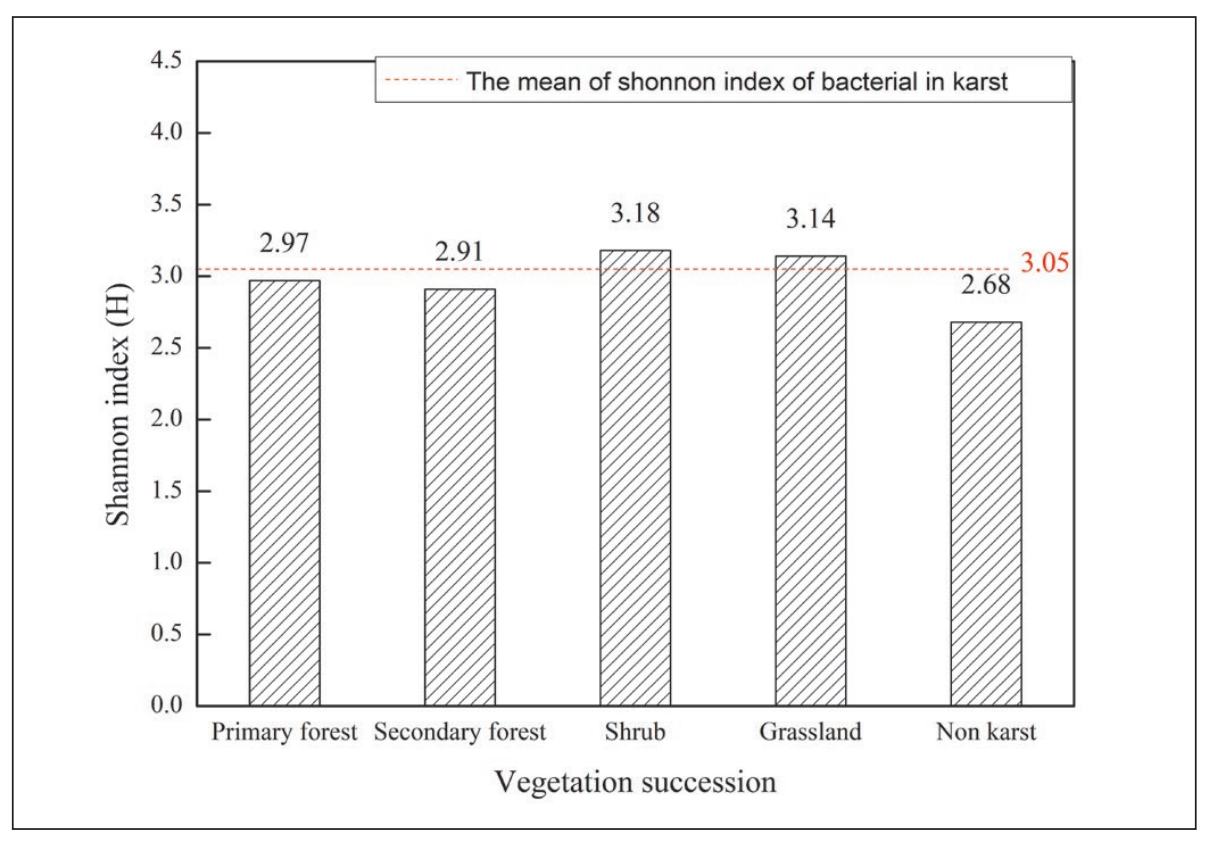

Figure 4: Shannon index from bacterial community between karst and non-karst area. 


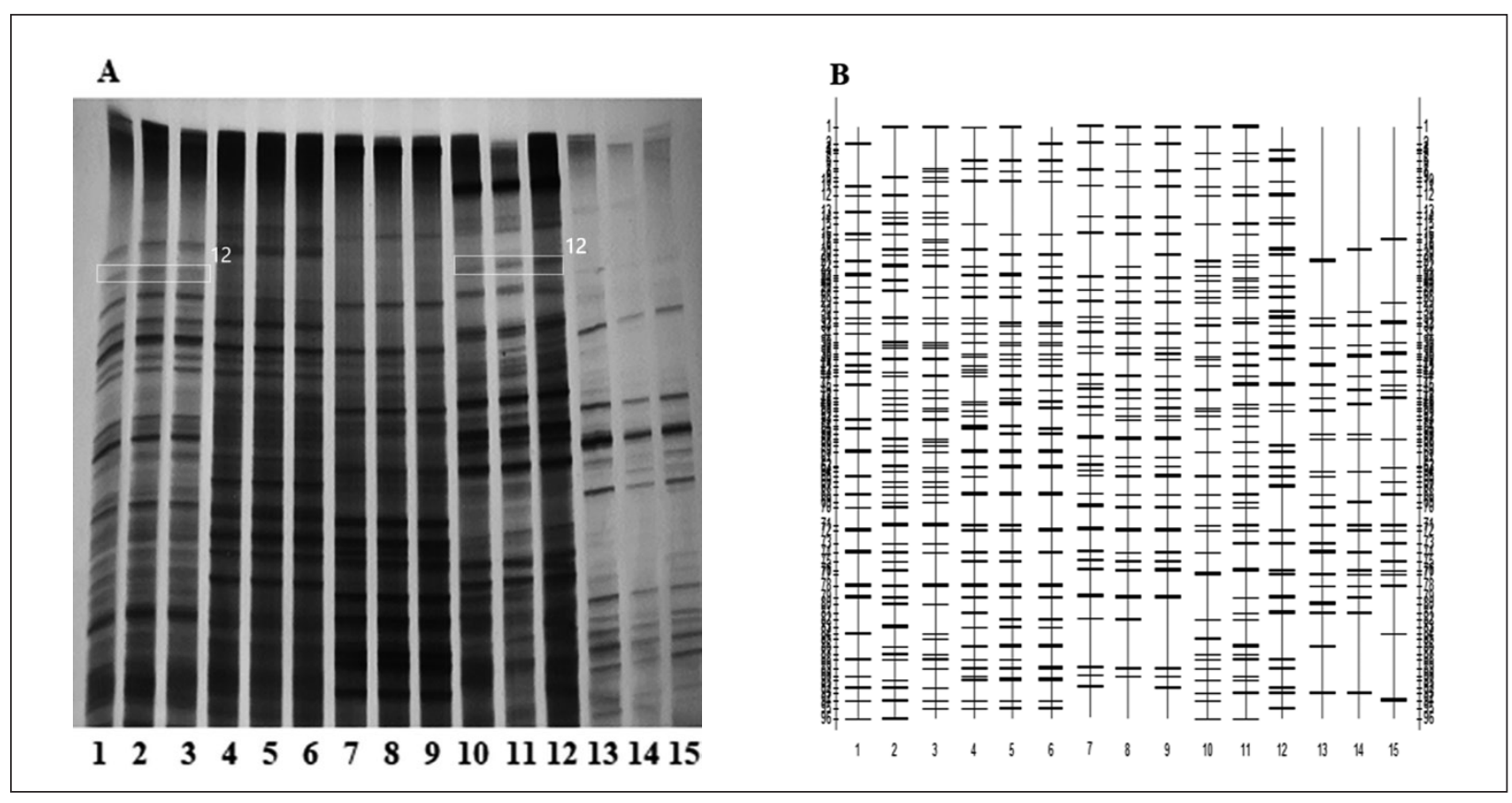

Figure 5: DGGE profile of amplified fungal communities in different vegetation succession samples. (A) DGGE page; (B) Comparison of bands pattern (Horizontal numbers: 1-3 secondary forest; 4-6 shrub; 7-9 primary forest; 10-12 grassland; $13-15$ non karst; Vertical numbers: 12 and 13 mark the positions of different bands.).

in karst soil. Samples 2 and 3 from the secondary forest showed the most abundant bands, which suggested that secondary forest had the highest fungal diversity. Samples 13, 14 and 15 from the non karst shared the minimum amount of bands compared with samples $1-12$, which indicated that the diversity of fungi in non karst areas was lower than that in karst areas. It was worth to note that the specific bands from the soil fungal community of each succession varied greatly among different samples. For example in shrub samples 4, 5 and 6 , a specific band no. 12 were not present while in the secondary forest (sample 1,2 and 3) both bands no. 12 and 13 could be seen. This kind of variation was more extravagant than that from the bacterial survey, which was possibly due to more bands detected in fungi DGGE page (96 bands detected in total). In general, the results indicated that the structure of fungal community has distinguished components within the vegetation succession process.

\section{CLUSTER ANALYSIS}

We performed the similarity clustering. As shown in Figure 6, the fungal communities from the shrub (sample 4-6) and primary forest (sample 7-9) were classified within the same branch of cluster, with a similarity of 0.35 . The fungal communities of sample 2 and 3 from the secondary forest were grouped with sample 12 from the grassland, and they stayed close with the above cluster on

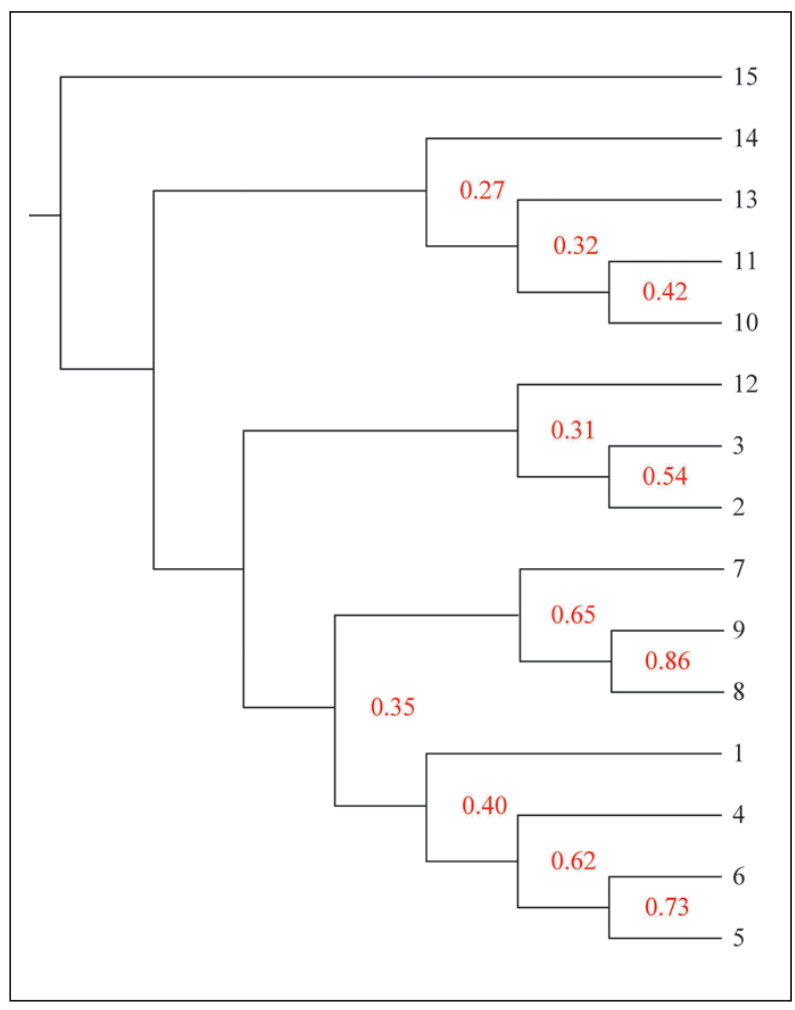

Figure 6: Similarity of fungal communities between different vegetation succession samples. Numbers above the branches represent the index. (1-3 secondary forest; 4-6 shrub; 7-9 primary forest; 10 12 grassland; 13-15 non karst). 
Table 4: The similarity index () between different vegetation succession samples offungal communities (\%). (1-3 secondary forest; 4-6 shrub; 7-9 primary forest; 10-12 grassland; 13-15 non karst).

\begin{tabular}{|c|c|c|c|c|c|c|c|c|c|c|c|c|c|c|c|}
\hline Sample & 1 & 2 & 3 & 4 & 5 & 6 & 7 & 8 & 9 & 10 & 11 & 12 & 13 & 14 & 15 \\
\hline 1 & 100.0 & 31.0 & 29.9 & 41.2 & 37.1 & 40.8 & 39.0 & 34.6 & 37.8 & 27.9 & 33.0 & 24.7 & 24.9 & 13.4 & 28.4 \\
\hline 2 & 31.0 & 100.0 & 53.9 & 38.1 & 36.2 & 29.9 & 33.7 & 32.4 & 33.2 & 27.3 & 36.8 & 32.9 & 25.8 & 28.5 & 24.8 \\
\hline 3 & 29.9 & 53.9 & 100.0 & 41.9 & 40.1 & 29.9 & 21.3 & 23.1 & 22.5 & 33.3 & 28.5 & 29.6 & 19.6 & 21.2 & 26.9 \\
\hline 4 & 41.2 & 38.1 & 41.9 & 100.0 & 69.9 & 53.2 & 29.2 & 28.2 & 25.4 & 30.3 & 39.3 & 37.7 & 22.6 & 29.1 & 26.1 \\
\hline 5 & 37.1 & 36.2 & 40.1 & 69.9 & 100.0 & 73.4 & 33.2 & 33.0 & 34.2 & 28.8 & 39.3 & 33.9 & 18.1 & 25.3 & 30.0 \\
\hline 6 & 40.8 & 29.9 & 29.9 & 53.2 & 73.4 & 100.0 & 42.4 & 40.6 & 42.8 & 26.3 & 30.6 & 27.1 & 14.9 & 18.9 & 24.1 \\
\hline 7 & 39.0 & 33.7 & 21.3 & 29.2 & 33.2 & 42.4 & 100.0 & 82.1 & 83.1 & 28.1 & 34.9 & 25.2 & 20.9 & 24.7 & 25.4 \\
\hline 8 & 34.6 & 32.4 & 23.1 & 28.2 & 33.0 & 40.6 & 82.1 & 100.0 & 86.1 & 31.5 & 35.8 & 23.7 & 16.2 & 22.3 & 22.9 \\
\hline 9 & 37.8 & 33.2 & 22.5 & 25.4 & 34.2 & 42.8 & 83.1 & 86.1 & 100.0 & 27.2 & 33.2 & 27.8 & 13.9 & 21.3 & 21.5 \\
\hline 10 & 27.9 & 27.3 & 33.3 & 30.3 & 28.8 & 26.3 & 28.1 & 31.5 & 27.2 & 100.0 & 42.3 & 20.8 & 31.1 & 23.9 & 20.8 \\
\hline 11 & 33.0 & 36.8 & 28.5 & 39.3 & 39.3 & 30.6 & 34.9 & 35.8 & 33.2 & 42.3 & 100.0 & 37.7 & 32.5 & 22.4 & 28.8 \\
\hline 12 & 24.7 & 32.9 & 29.6 & 37.7 & 33.9 & 27.1 & 25.2 & 23.7 & 27.8 & 20.8 & 37.7 & 100.0 & 22.0 & 26.1 & 12.5 \\
\hline 13 & 24.9 & 25.8 & 19.6 & 22.6 & 18.1 & 14.9 & 20.9 & 16.2 & 13.9 & 31.1 & 32.5 & 22.0 & 100.0 & 30.9 & 21.0 \\
\hline 14 & 13.4 & 28.5 & 21.2 & 29.1 & 25.3 & 18.9 & 24.7 & 22.3 & 21.3 & 23.9 & 22.4 & 26.1 & 30.9 & 100.0 & 18.5 \\
\hline 15 & 28.4 & 24.8 & 26.9 & 26.1 & 30.0 & 24.1 & 25.4 & 22.9 & 21.5 & 20.8 & 28.8 & 12.5 & 21.0 & 18.5 & 100.0 \\
\hline
\end{tabular}

a separate branch. Besides, sample 10 and 11 from grassland, they stayed closer (a similarity of 0.42 ) and they together shared a similarity of 0.32 with the non karst sample 13. It was obviously that the similarity was diffused along with the succession process. From the similarity $C s$ index (Table 4), overall within same vegetation succession, samples had higher index correlation. For example, the sample 7, 8 and 9 were from the same cluster branch and the $C s$ index between them were $82.1 \%, 83.1 \%$ and $86.1 \%$. But compared the sample 7 with others than 8 and 9 , it showed values of index correlation ranging from $20.9 \%$ (v.s sample 13) to $42.4 \%$ (v.s sample 6). This pat- tern can be found in other samples as well. Therefore the fungal communities along with different vegetation successions had significant distinction.

\section{Diversity and Richness analysis}

Soil fungal communities Shannon index, richness and evenness in different vegetation succession samples were shown in Table 5. It can be seen that the lowest Shannon index and richness index of soil fungi in karst vegetation succession were the primary forest (3.56 and 35). In addition to the primary forest, the difference of fungal Shannon index and richness in karst vegetation succession was

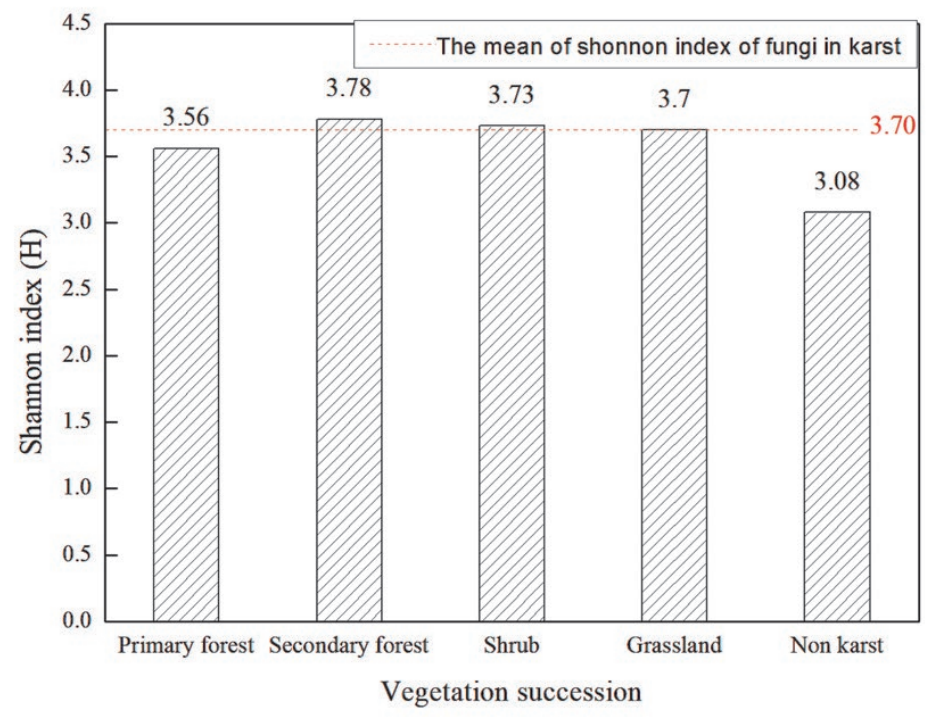

Vegetation succession
Figure 7: Shannon index from fungal community between karst and non-karst area. 
YIDONG MI, HONGDA FANG, PENG TAO, MIN ZHOU, XINRU LI, FANFAN WANG, HAIYAN CHEN, HAILEI SU, YUANRONG ZHU, YUAN WEI \& LIN XI

Table 5: Shannon index, richness and evenness of fungal communities in different vegetation succession stage samples.

\begin{tabular}{|c|c|c|c|}
\hline Vegetation succession & Shannon index $(\mathrm{H})$ & Richness (S) & Evenness (EH) \\
\hline Primary forest & $3.56 \pm 0.02 b$ & $35 b$ & $1.00 \pm 0.00 a$ \\
\hline Secondary forest & $3.78 \pm 0.25 a$ & $45 a$ & $1.00 \pm 0.00 a$ \\
\hline Shrub & $3.73 \pm 0.10 a$ & $42 a$ & $1.00 \pm 0.00 a$ \\
\hline Grassland & $3.70 \pm 0.13 a$ & $40 a$ & $1.00 \pm 0.00 a$ \\
\hline Non karst & $3.08 \pm 0.04 c$ & $22 c$ & $1.00 \pm 0.00 \mathrm{a}$ \\
\hline
\end{tabular}

Note: Data are the means \pm SD (Different letters “a, b, c," in the same column indicate significant differences at $\mathrm{P}<0.05$ with Tukey test for multiple comparisons.)

not significant. The Shannon index and richness in secondary forest, shrub and grassland were 3.78 and $45,3.73$ and $42,3.70$ and 40 , respectively. Besides, the Shannon index and richness of non karst samples were 3.08 and 22, which were significantly lower than the levels of karst vegetation succession. The mean difference in fungal Shannon index between karst areas (3.70) and non karst areas (3.08) was 0.62 (Figure 7), significantly greater than that in bacterial Shannon index (0.37) (Figure 4), which indicated that the difference of fungal diversity between karst areas and non karst areas was more significant than bacterial diversity. The trends of fungal Shannon index and the richness was compared as follows: secondary forest $>$ shrubbery $>$ grassland $>$ primary forest. There was no difference between the evenness index values from each ecological succession.

\section{DISCUSSION}

In the present research, the diversity of bacteria and fungi in karst vegetation succession was studied using PCRDGGE technology, and the results showed that abundant species of bacteria and fungi can be detected from karst vegetation succession areas. The ecological environment in karst areas is complex and diverse, species must adapt to this environment to survive. The abundant microbial diversity in karst is the result of long-term selection of ecological environment, which is conducive to maintaining the continuity and comprehensiveness of its functions ( Zhu et al., 2012; Tang et al., 2017).

In this study, similarity cluster analysis for both bacteria and fungi communities provided that the conservation and diversity behavior were distinguished in karst vegetation succession, which indicated that the soil microorganism community structure changed greatly with the conversion of vegetation succession. Pan et al. (2018) investigated litter and soil nutrients on soil enzyme activities and microbial biomass along vegetation successions in karst region, and indicated that the litter nutrients and quantities had direct positive effect on soil nutrients, which had direct effect on enzyme activities and microbial biomass. Nutrient could be one of the key factors affecting the structure of microbial community. Meanwhile, plant community structure changing lead to alteration of microbial community structure, which have a significant impact on the decomposers (Lamb et al.,
2010). Previous studies also support our view that plant communities are important factors affecting microbial diversity (Schlatter et al., 2015).

Compared with the results from bacteria study, the differences of fungal diversity between karst areas and non karst areas were more obvious. Soil fungi participate in the decomposition of plant and animal remains, which is the most indispensable source in the soil carbon and nitrogen cycle, especially in the early stage of plant remains decomposition, fungi are more active than bacteria (Clemmensen et al., 2013). With the succession of vegetation, the composition of plant community and the source of carbon in soil changed significantly, which leads to alterations of the fungal community structure in soil (Wang et al., 2013). Besides, both fungi and bacteria in karst areas have high diversity in our result. Previous study reported that bacteria and fungi have great complementarity in ecological function to form healthy karst soil microbiota (Liang et al., 2016). Abundant microbial diversity may determine the rate of material cycling in a karst ecosystem thereby affects plant community diversity and productivity (Li et al., 2014).

The Shannon index, richness and evenness of bacteria and fungi in different vegetation succession stages were analyzed in this study. The patterns identified from the bacterial survey for Shannon diversity index and the richness comprehensively was evaluated as follows: 
shrub $>$ grassland $>$ primary forest $>$ secondary forest $>$ non karst, bacterial diversity tends to increase firstly from grassland to shrub and then decrease gradually to be stable with the positive succession of vegetation from shrub to secondary forest. This result is consistent with the latest research of using high-throughput sequencing technology to study the structure of soil bacterial community in karst areas (Liu et al., 2015a). The main reason is that soil fertility is low and soil heterogeneity increased in the early stage of vegetation succession, which increased the diversity of soil bacterial community (Liu et al., 2015b). Based on our result, with the positive succession of the ecosystem, the composition and structure of the ecosystem tended to be complete and stable (Loreau \& de Mazancourt, 2013), and some bacteria in the intermediate of succession are eliminated. It has been known that there is a positive correlation between soil microbial metabolic diversities and plant taxonomic diversity ( $\mathrm{He}$ et al., 2008).

The trends of fungal Shannon index and the richness were identified as follows: secondary forest $>$ shrubbery $>$ grassland $>$ primary forest $>$ non karst. At the same time, through the comprehensive analysis of the Shannon index, richness and evenness of fungi in different vegetation successions, the karst ecological succession had a significant impact on the fungal community structure. Bastias et al. (2007) studied the effect of forest type conversion on soil fungal diversity by PCR-TFLP and DGGE technology, and found that the change of forest type affected the diversity of soil fungal community greatly, which supported our results (Harpole \& Tilman, 2007). Unlike the pattern from the bacteria survey, in fungal communities, Shannon index and the richness showed that the secondary forest showed the highest values. Zhu et al. (2012) found that the Shannon indexes of fungi was positively correlated with the contents of soil organic carbon, total nitrogen and cation exchange capacity. With the vegetation succession (from farming system to tussock, shrub and secondary forest), soil organic carbon, total nitrogen and physical conditions were significantly improved, which resulted in the increases of soil fungal phylogenetic diversity (Zhu et al., 2012). Soil fungal communities are often strongly influenced by soil nutrient (Gomez-Brandon et al., 2020; Xu et al., 2021). Numerous studies have demonstrated that vegetation succession could alter and gradually restore soil nutrients (Jiao et al., 2011; Zhang et al., 2021). The plants in secondary forests in the study area include leguminous plants and non-leguminous plants, leguminous plants have the ability to enter into symbiosis with nitrogen-fixing bacteria (Liang et al., 2016), which can increased soil nutrients (Zhang et al., 2020b). This may be the reason for the high fungal diversity in secondary forests.

Studies have shown that fungi in the upper layer of soil are often associated with the decomposition of litter (Kubartova et al., 2009; Zhang et al., 2020a). With the positive succession of vegetation in karst, the composition and quantity of litters change greatly (Pan et al., 2018). It is obvious that different succession required different fungal communities to play their important ecological functions. This study mainly collected topsoil, which indicated that litters could be the main reason for the great changes in the fungal community.

\section{ACKNOWLEDGMENT}

This work was funded by the National Natural Science Foundation of China (41977294), Ministry of Sci- ence and Technology of the People's Republic of China (2016R1A6A1A05011910).

\section{REFERENCES}

Bassam, B.J., Caetano-Anollés, G., Gresshoff, P.M., 1991. Fast and sensitive silver staining of DNA in polyacrylamide gels. Analytical Biochemistry, 196(1): 80-83. https://doi.org/10.1016/00032697(91)90120-i

Bastias, B.A., Anderson, I.C., Xu, Z., Cairney, J.W.G., 2007. RNA- and DNA-based profiling of soil fungal communities in a native Australian eucalypt forest and adjacent Pinus elliotti plantation. Soil Biology and Biochemistry, 39(12): 3108-3114. http://doi. org/10.1016/j.soilbio.2007.06.022

Blagodatskaya, E., Kuzyakov, Y., 2013. Active microorganisms in soil: Critical review of estimation criteria and approaches. Soil Biology and Biochem- 
istry, 67: 192-211. http://doi.org/10.1016/j.soilbio.2013.08.024

Carney, K.M., Matson, P.A., 2005. Plant communities, soil microorganisms, and soil carbon cycling: Does altering the world belowground matter to ecosystem functioning? Ecosystems, 8: 928-940. http:// doi.org/10.1007/s10021-005-0047-0

Chen, H., Li, D., Mao, Q., Xiao, K., Wang, K., 2019. Resource limitation of soil microbes in karst ecosystems. Sci Total Environ, 650(Part 1): 241-248. http:// doi.org/10.1016/j.scitotenv.2018.09.036

Clemmensen, K.E., Bahr, A., Ovaskainen, O., Dahlberg, A., Ekblad, A., Wallander, H., Stenlid, J., Finlay, R.D., Wardle, D.A., Lindahl, B.D., 2013. Roots and associated fungi drive long-term carbon sequestration in boreal forest. Science, 339(6127): 1615-1618. http://doi.org/10.1126/science.1231923

Fan, Z., Lu, S., Liu, S., Guo, H., Wang, T., Zhou, J., Peng, X., 2019. Changes in plant rhizosphere microbial communities under different vegetation restoration patterns in karst and non-karst ecosystems. Scientific Reports, 9: 8761. http://doi.org/10.1038/s41598019-44985-8

Gomez-Brandon, M., Probst, M., Siles, J.A., Peintner, U., Bardelli, T., Egli, M., Insam, H., Ascher-Jenull, J., 2020. Fungal communities and their association with nitrogen-fixing bacteria affect early decomposition of Norway spruce deadwood. Scientific Reports, 10: 8025. http://doi.org/10.1038/s41598-02064808-5

Harpole, W.S., Tilman, D., 2007. Grassland species loss resulting from reduced niche dimension. Nature, 446: 791-793. http://doi.org/10.1038/nature05684

He, X., Wang, K., Zhang, W., Chen, Z., Zhu, Y., Chen, H., 2008. Positive correlation between soil bacterial metabolic and plant species diversity and bacterial and fungal diversity in a vegetation succession on Karst. Plant and Soil, 307: 123-134. http://doi. org/10.1007/s11104-008-9590-8

Hui, N., Sun, N., Du, H., Umair, M., Kang, H., Liu, X., Romantschuk, M., Liu, C., 2019. Karst rocky desertification does not erode ectomycorrhizal fungal species richness but alters microbial community structure. Plant and Soil, 445: 383-396. http://doi. org/10.1007/s11104-019-04319-Z

Jiang, Z., Lian, Y., Qin, X., 2014. Rocky desertification in Southwest China: Impacts, causes, and restoration. Earth-Science Reviews, 132: 1-12. http://doi. org/10.1016/j.earscirev.2014.01.005

Jiao, F., Wen, Z.M., An, S.S., 2011. Changes in soil properties across a chronosequence of vegetation restoration on the Loess Plateau of China. Cat- ena, 86(2): 110-116. http://doi.org/10.1016/j.catena.2011.03.001

Kubartova, A., Ranger, J., Berthelin, J., Beguiristain, T., 2009. Diversity and decomposing ability of saprophytic fungi from temperate forest litter. Microbial Ecology, 58: 98-107. http://doi.org/10.1007/s00248008-9458-8

Kumar, M., Männistö, M.K.,van Elsas, J.D., Nissinen, R.M., 2015. Plants impact structure and function of bacterial communities in Arctic soils. Plant and Soil, 399: 319-332. http://doi.org/10.1007/s11104015-2702-3

Lamb, E.G., Kennedy, N., Siciliano, S.D., 2010. Effects of plant species richness and evenness on soil microbial community diversity and function. Plant and Soil, 338: 483-495. http://doi.org/10.1007/s11104010-0560-6

Li, L., Wang, D., Liu, X., Zhang, B., Liu, Y., Xie, T., Du, Y., Pan, G., 2013. Soil organic carbon fractions and microbial community and functions under changes in vegetation: A case of vegetation succession in karst forest. Environmental Earth Sciences, 71: 37273735. http://doi.org/10.1007/s12665-013-2767-3

Li, Y., Chen, L., Wen, H., Zhou, T., Zhang, T., 2014. Pyrosequencing-based assessment of bacterial community structure in mine soils affected by mining subsidence. International Journal of Mining Science and Technology, 24(5): 701-706. http://doi. org/10.1016/j.ijmst.2014.07.002

Liang, Y., Pan, F., He, X., Chen, X., Su, Y., 2016. Effect of vegetation types on soil arbuscular mycorrhizal fungi and nitrogen-fixing bacterial communities in a karst region. Environmental Science and Pollution Research, 23, 18482-18491. http://doi.org/10.1007/ s11356-016-7022-5

Liu, S., Zhang, W., Wang, K., Pan, F., Yang, S., Shu, S., 2015a. Factors controlling accumulation of soil organic carbon along vegetation succession in a typical karst region in Southwest China. Science of The Total Environment, 521-522: 52-58. http://doi. org/10.1016/j.scitotenv.2015.03.074

Liu, X., Wang, S., Liu, X., Huang, T., Yong, L., $2015 b$. Compositional characteristic and variations of soil microbial community in karst area of Puding Country, Guizhou Province, China. Earth and Environment, 43(5): 490-497. http://doi.org/10.14050/j. cnki.1672-9250.2015.05.002

Liu, C., Liu, Y., Guo, K., Qiao, X., Zhao, H., Wang, S., Zhang, L., Cai, X., 2018. Effects of nitrogen, phosphorus and potassium addition on the productivity of a karst grassland: Plant functional group and community perspectives. Ecological Engineering, 117: 84-95. http://doi.org/10.1016/j.ecoleng.2018.04.008 
Loreau, M., de Mazancourt, C., 2013. Biodiversity and ecosystem stability: A synthesis of underlying mechanisms. Ecology Letters, 16(s1): 106-115. https://doi.org/10.1111/ele.12073

Luo, H.F. ,Qi, H.Y., Zhang, H.X., 2004. Assessment of the bacterial diversity in fenvalerate-treated soil. World Journal of Microbiology and Biotechnology, 20: 509-515. http://doi.org/10.1023/ B:WIBI.0000040401.46606.a4

Ma, T., Deng, X., Chen, L., Xiang, W., 2020. The soil properties and their effects on plant diversity in different degrees of rocky desertification. Science of Total Environment, 736: 139667. http://doi.org/10.1016/j. scitotenv.2020.139667

Muyzer, G., de Waal, E.C., Uitterlinden, A.G., 1993. Profiling of complex microbial populations by denaturing gradient gel electrophoresis analysis of polymerase chain reaction-amplified genes coding for 16S rRNA. Applied and Environmental Microbiology, 59(3): 695-700.

Pan, F., Zhang, W., Liang, Y., Liu, S., Wang, K., 2018. Increased associated effects of topography and litter and soil nutrients on soil enzyme activities and microbial biomass along vegetation successions in karst ecosystem, southwestern China. Environmental Science and Pollution Research, 25: 1697916990. https://doi.org/10.1007/s11356-018-1673-3

Schlatter, D.C. ,Bakker, M.G., Bradeen, J.M., Kinkel, L.L., 2015. Plant community richness and microbial interactions structure bacterial communities in soil. Ecology, 96(1): 134-142. https://doi.org/10.1890/131648.1

Tang, Y., Cheng, J., Lian, B., 2017. Characterization of endolithic culturable microbial communities in carbonate rocks from a typical karst canyon in Guizhou (China). Polish Journal of Microbiology, 65: 413423. https://doi.org/10.5604/17331331.1227667

Wang, M., Qu, L., Ma, K., Yuan, X., 2013. Soil microbial properties under different vegetation types on Mountain Han. Science China Life Sciences, 56: 561-570. https://doi.org/10.1007/s11427-013-44860

Wang, S.J., Liu, Q.M., Zhang, D.F., 2004. Karst rocky desertification in southwestern China: geomorphology, landuse, impact and rehabilitation. Land Degradation and Development, 15(2): 115-121. https:// doi.org/10.1002/ldr.592

Wang, S., Lu, H., Zhou, Y., Xie, L., Xiao, D., 2007. Spatial variability of soil organic carbon and representative soil sampling method in Maolan karst virgin forest. Acta Pedologica Sinica, 44: 475-483. (in chinese)

Wei, Y., Yu, L.F., Zhang, J.C., Yu, Y.C., Deangelis, D.L., 2011. Relationship between vegetation restoration and soil microbial characteristics in degraded karst regions: A case study. Pedosphere, 21(1): 132-138. https://doi.org/10.1016/s1002-0160(10)60088-4

Wei, Y., Wang, S., Liu, X., Huang, T., 2012. Molecular diversity and distribution of arbuscular mycorrhizal fungi in karst ecosystem, Southwest China. African Journal Of Biotechnology, 11(80): 14561-14568. https://doi.org/10.5897/ajb12.587

Wu, X., Liu, S., Cheng, F., Hou, X., Zhang, Y., Dong, S., Liu, G., 2018. A regional strategy for ecological sustainability: A case study in Southwest China. Science of the Total Environment, 616-617: 1224-1234. https://doi.org/10.1016/j.scitotenv.2017.10.196

Xu, H., Du, H., Zeng, F., Song, T., Peng, W., 2021. Diminished rhizosphere and bulk soil microbial abundance and diversity across succession stages in Karst area, southwest China. Applied Soil Ecology, 158: 103799. https://doi.org/10.1016/j.apsoil.2020.103799

Yan, Y., Dai, Q., Hu, G., Jiao, Q., Mei, L., Fu, W., 2020. Effects of vegetation type on the microbial characteristics of the fissure soil-plant systems in karst rocky desertification regions of SW China. Science of the Total Environment, 712: 136543. https://doi. org/10.1016/j.scitotenv.2020.136543

Yu, Y., Shen, W., Yin, Y., Zhang, J., Cai, Z., Zhong, W., 2012. Response of soil microbial diversity to landuse conversion of natural forests to plantations in a subtropical mountainous area of southern China. Soil Science and Plant Nutrition, 58: 450-461. https://doi.org/10.1080/00380768.2012.708645

Zhang, M., Wang, K., Liu, H., Zhang, C., Wang, J., Yue, Y., Qi, X., 2015. How ecological restoration alters ecosystem services: an analysis of vegetation carbon sequestration in the karst area of northwest Guangxi, China. Environmental Earth Sciences, 74: 5307-5317. https://doi.org/10.1007/s12665015-4542-0

Zhang, N., Bruelheide, H., Li, Y., Liang, Y., Wubet, T., Trogisch, S., Ma, K., 2020a: Community and neighbourhood tree species richness effects on fungal species in leaf litter. Fungal Ecology, 47: 100961. https://doi.org/10.1016/j.funeco.2020.100961

Zhang, Y., Hou, L., Li, Z., Zhao, D., Song, L., Shao, G., Ai, J., Sun, Q., 2020b: Leguminous supplementation increases the resilience of soil microbial community and nutrients in Chinese fir plantations. Science of the Total Environment, 703: 134917. https:/doi. org/10.1016/j.scitotenv.2019.134917

Zhang, Y., Xu, X., Li, Z., Xu, C., Luo, W., 2021. Improvements in soil quality with vegetation succession in subtropical China karst. Science of the Total Envi- 
ronment, 775(6): 145876. https://doi.org/10.1016/j. scitotenv.2021.145876

Zhao, J., Li, S., He, X., Liu, L., Wang, K., 2014. The soil biota composition along a progressive succession of secondary vegetation in a karst area. PloS one, 9(11): | e112436. https://doi.org/10.1371/journal. pone.0112436.t001

Zhou, L., Wang, X., Wang, Z., Zhang, X., Chen, C., Liu, H., 2020. The challenge of soil loss control and vegetation restoration in the karst area of southwestern China. International Soil and Water Conservation
Research, 8(1): 26-34. https://doi.org/10.1016/j. iswcr.2019.12.001

Zhou, Z., 1987. Scientific survey of the Maolan karst forest. Guizhou People's Press, Guiyang, pp.1-23. (in chinese)

Zhu, H., He, X., Wang, K., Su, Y., Wu, J., 2012. Interactions of vegetation succession, soil bio-chemical properties and microbial communities in a Karst ecosystem. European Journal of Soil Biology, 51: 1-7. https://doi.org/10.1016/j.ejsobi.2012.03.003 